\title{
Antibiotic sterilization of cadaveric homograft aortic valve for clinical use
}

\author{
Rezwanul Hoque ${ }^{1}$, Zulfiqar Rashid ${ }^{2}$ and Sunil Kumar Sarkar ${ }^{2}$ \\ Department of Cardiac Surgery, ${ }^{1}$ Bangabandhu Sheikh Mujib Medical University, Shahbag, Dhaka; ${ }^{2}$ National \\ Institute for Cardiovascular Diseases, Dhaka, Bangladesh. e-mail: rhbulbul@yahoo.com (RH)
}

Since the first cardiac valve replacement in the early sixth decade of the last century, the search continued for ideal cardiac valve substitute with proven structural durability over a period of 10 to 20 years, central flow orifice without transvalvular gradient, absence of host reactivity deleterious to valve function, non-thrombogenecity without the use of anti-coagulant, resistance to infective endocarditis, availability with cost effectiveness and ease of surgical implantation ${ }^{1}$. The experience with prosthetic tissue valves commenced almost simultaneously with the silastic ball valve and the aortic homograft valve. Homograft aortic valves have been used either as fresh, antibiotic sterilized or cryo-preserved, as a replacement for mitral valve, aortic valve, aortic root replacement, or a conduit between the right ventricle and the pulmonary trunk.

Homograft cardiac valve or valve conduit is used in correcting some congenital malformation in childhood, in old age because of higher rate of complication of either bleeding or thromboembolism from anticoagulant used along with mechanical valves, in women wanting a child because of the risk of embryopathy or CNS defect from warfarin anticoagulant, patients with risk of hemorrhage from chronic liver disease, active peptic ulcer, bleeding diathesis, in refractory cases of prosthetic valve endocarditis or native valve endocarditis.

Fresh sterile homograft is difficult to procure so a method of sterilizing contaminated heart valve from autopsy specimen using low concentration of antibiotic cocktail is needed before its storage by cryo-preservation method.

\section{Materials and Methods}

Thirty heart specimens of human cadavers (autopsy done within 6 hours of death) were collected from the morgue of Dhaka Medical College Hospital from January to December, 1998 at the time of autopsy using clean procedure with sterile gloves and instruments. Permission from the local ethical committee was taken in the proper way. After rinsing with sterile saline the heart and $200 \mathrm{ml}$ of saline solution were placed sequentially in a sterile plastic bag, a second bag, a lid-sealed plastic container, another bag and ice-filled chaste. The temperature was maintained at $4^{0} \mathrm{C}$ during rapid transfer to the laboratory. Prompt dissection of the homograft from the fresh heart in an aseptic environment using standard surgical technique was done. A strip of tissue was cut from aorta and divided into 18 pieces ( 3 pieces for histology). One piece of aortic wall was subjected to pre-sterilization histological examination. In the control group, the remaining 10 pieces of aortic tissue were put into another sterile jar and $10 \mathrm{ml}$ of final rinse with modified Hanks' solution was added. One piece of aortic wall tissue was subjected to subsequent histological examination after 48 hours.

In the experimental group, valve and seven pieces of aortic tissue were placed in sterile antibiotic Hanks' solution (modified CLPVA solution composed of ceftriaxone $250 \mu \mathrm{g} / 1$, lincomycin 120 $\mu \mathrm{g} / \mathrm{l}$, polymyxin B $100 \mu \mathrm{g} / \mathrm{l}$, vancomycin $50 \mu \mathrm{g} / \mathrm{l}$ and amphotericin B $25 \mu \mathrm{g} / \mathrm{l})^{2}$, one piece of which was subjected to post-sterilization histological examination after 48 hours. Both groups were cultured before freezing at $4^{0} \mathrm{C}$, at 24 hours of freezing, and 48 hours of freezing at $4^{\circ} \mathrm{C}$. Before antibiotic decontamination, 1 piece of aortic wall tissue was cultured in Thioglycollate broth at $37^{\circ} \mathrm{C}$, one piece in Sabouraud dextrose broth $\left(27^{0} \mathrm{C}\right.$ for 6 weeks) to detect candida and fungal contamination, one piece was subjected to anaerobic stab culture. Other studies were done to identify microorganism using standard protocol. The sequences were repeated after antibiotic decontamination at 24 hours of freezing at $4^{0} \mathrm{C}$, and at 48 hours of freezing at $4^{0} \mathrm{C}$. Data were collected in tabulated form. Significance of proportions was calculated by ChiSquare $\left(\chi^{2}\right)$ test. Level of significance was fixed at $\mathrm{p}<0.05$. 


\section{Results}

The warm ischemic time which includes harvesting time and dissection time was $357.5 \pm 40.7 \mathrm{~min}$ (range $325-505 \mathrm{~min}$ ). All the 30 valves were contaminated with Gram-positive cocci, (Staphylococcus aureus being the major contaminant), 9 were also contaminated with Gram-negative bacilli and 3 were contaminated by Candida albicans (Table I). The antibiotic cocktail was found to be effective against $S$. aureus, $S$. epidermidis, $S$. pyogenes, $P$. mirabilis, and $K$.pneumonia. Of the total 30 specimens, the antibiotic solution decontaminated 21 specimens, the remaining 9 showed the persistence of micro-organisms even after 48 hours of antibiotic sterilization. The entire control specimen showed persistence of micro-organism even after 48 hours of refrigeration with modified Hanks' balanced salt solution. Gross tissue architecture remained unchanged in the antibiotic decontaminated specimens whereas in the control group and in the 9 experimental specimens with persistence positivity for micro-organisms showed early necrotic changes. Statistical analysis showed that the CLPVA cocktail was highly effective $(\mathrm{p}<0.001)$.

Table 1: Presence of micro-organism in the heart specimen of human cadaver before and after treatment with antibiotic solution

\begin{tabular}{lccc}
\hline \multirow{2}{*}{$\begin{array}{l}\text { Micro- } \\
\text { organism }\end{array}$} & $\begin{array}{c}\text { Pre- } \\
\text { sterilization }\end{array}$ & $\begin{array}{c}\text { Without } \\
\text { antibiotic } \\
\text { solution }\end{array}$ & $\begin{array}{c}\text { With } \\
\text { antibiotic } \\
\text { solution }\end{array}$ \\
\cline { 2 - 4 } & 21 & 21 & 6 \\
\hline $\begin{array}{l}\text { Staphylococcus } \\
\text { aureus } \\
\begin{array}{l}\text { Staphylococcus } \\
\text { epidermidis }\end{array}\end{array}$ & 6 & 6 & 3 \\
$\begin{array}{l}\text { Streptococcus } \\
\text { pyogenes }\end{array}$ & 3 & 3 & 0 \\
$\begin{array}{l}\text { Proteus } \\
\text { mirabilis }\end{array}$ & 3 & 3 & 0 \\
$\begin{array}{l}\text { Pseudomonus } \\
\text { aeurigenosa }\end{array}$ & 3 & 3 & 3 \\
$\begin{array}{l}\text { Klebsiella } \\
\text { pneumonia } \\
\begin{array}{l}\text { Candida } \\
\text { albicans }\end{array}\end{array}$ & 3 & 3 & 0 \\
\hline
\end{tabular}

\section{Discussion}

Sterilized homograft aortic valve can be used with success. Aortic valve can be collected from two categories of donor: a) from beating heart in brain death cases within a maximum delay of 18 hours for collection after declaration of brain death and $b$ ) non-beating hearts (hospital and forensic cases) with post-mortem delay of 24 hours or less (in no case more than 36 hours). In the case of a non- beating heart donor, it is extremely important to maintain a limited post mortem delay and to keep the warm ischemic time (time between death and refrigeration at $2-4^{0} \mathrm{C}$ ) as short as possible (less than 6 hours) ${ }^{3}$.

Wright et al, (1979) observed that if the dead body was cooled to $4^{0} \mathrm{C}$ following death within 6 hours and was refrigerated, the valves might be collected within 48 hours of death to preserve tissue integrity and cell viability ${ }^{4}$.

In this study, the selection criteria advocated by Kirklin et al, (1993) had been used ${ }^{5}$. Valve dissection should be rapid, meticulous, with strict adherence to aseptic rituals preferably in a laminar flow cabinet. The present study showed that the mean total warm ischemic time was $357.5 \pm 40.76$ minutes. Only in 15 cases it was possible to keep the warm ischemic time less than 6 hours (360 minutes). The main purpose of keeping the warm ischemic time within 6 hours is to keep fibroblasts and endothelial cells viable to allow growth and to prevent early degenerative changes ${ }^{1}$.

A series of 40 patients received, early in 1967, fresh, aortic homograft valves procured under sterile conditions. The valves were implanted as free grafts in the sub coronary position. During a follow-up interval of 11 months there were five hospital deaths and one late death, none due to homograft dysfunction. All 34 surviving patients were either asymptomatic or greatly improved ${ }^{1}$.

The results of this clinical series and of continued experimental follow-up prompted the construction of premounted fresh homograft valves on a stent to enable the insertion of homograft in other intracardiac positions. A series of 13 canine implants in the mitral position were done with no mortality and good hemodynamic function, and thus, in March 1967, this frame-mounted preparation was employed clinically. During the following year, 31 patients received fresh aortic homograft valves mounted on a cloth-covered symmetrical metal support. The valves were implanted in the mitral position with good post-operative results. Successful multiple valve replacement with mounted fresh aortic homograft prompted efforts to solve the problems of guaranteed sterility, prolonged storage and ready availability ${ }^{1}$. Fresh sterile homograft is difficult to procure so a method of sterilizing contaminated heart valve from autopsy specimen using low concentration of antibiotic cocktail is needed before its storage by cryo-preservation method.

Goffin Y and associates showed that of 974 hearts harvested, $155(15.9 \%)$ were contaminated. The 
origins of contaminated hearts were as follows: non-beating hearts 98 (63.2\%); beating hearts from multiorgan donors, $46 \quad(29.6 \%)$; and heart transplanttation $11(7.1 \%)$. Out of these 155 hearts, $104(67.1 \%)$ developed contamination by Grampositive cocci; $36(23.2 \%)$ by Gram-negative organism; $7(4.5 \%)$ by yeast and fungi; $5(3.2 \%)$ by anaerobes and only $3(1.9 \%)$ by Gram-positive rods. Of these 155 hearts, $43(27.7 \%)$ remained contaminated after antibiotic sterilization ${ }^{3}$.

To sterilize the contaminated heart valves, an experiment was undertaken between January 1967 and March 1970, in which over 500 fresh aortic homograft valves were removed from human donors under sterile conditions and stored in solutions containing penicillin (100 units $/ \mathrm{ml}$ ), streptomycin $(100 \mu \mathrm{g} / \mathrm{ml})$, and amphotericin B $(0.25 \mu \mathrm{g} / \mathrm{ml})$ at $4^{0} \mathrm{C}$ for 2 to 5 days prior to use. Two hundred and thirty seven of these allograft valves were implanted clinically. At three years of follow-up, this series revealed an incidence of tissue failure of 12.2 percent and incidence of valve related mortality of 3.8 percent ${ }^{1}$.

Antibiotic sterilization was being simultaneously employed by Barrat-Boyes, Mohris and Bolookis groups. The concentrations of the antibiotics used were high and while efficacious for sterility these methods consistently yielded non-viable valves ${ }^{1}$.

Strickett et al., (1983) used another combination of antibiotics (CLPVA) in low concentration with success. The combination included: cefoxitin, (240 $\mu \mathrm{g} / \mathrm{l})$, lincomycin $(120 \mu \mathrm{g} / \mathrm{l})$, polymyxin B (100 $\mu \mathrm{g} / \mathrm{l})$, vancomycin $(50 \mu \mathrm{g} / \mathrm{l})$ and amphotericin $\mathrm{B}$ $(25 \mu \mathrm{g} / \mathrm{l})$.

In this study a modified low concentration of antimicrobial combination as advised by Strickett and co-workers was used. Ceftriaxone $250 \mu \mathrm{g} / 1$ was used in place of cefoxitin. This antimicrobial concentration was effective in decontaminating 21 valves $(70 \%), 9$ valves $(30 \%)$ showed persistence of contamination predominantly by Staphylococci sp. This result is comparable to the experience gathered at EHB where $29.6 \%$ remained contaminated after antibiotic sterilization ${ }^{3}$.

Lang and co-worker (1994) studied the biochemical and cellular characterization of cardiac valve tissue after cryo-preservation or antibiotic preservation. They found no significant alterations in the structure of any of the tissue components after antibiotic preservation or cryo-preservation; however, only endothelial cells from tissue stored by cryo-preservation retained the capacity to proliferate in vitro ${ }^{6}$.
Tabaku et al., in a recent study assessed the effectiveness of antimicrobial treatment using cool decontamination protocol with low concentration of antibiotics during processing of cardiovascular homografts. 948 homografts processed during a 2year period were analyzed. The overall rate of sterility in the end of processing is $94 \%$ and the most predominant germ in contamination was coagulase negative Staphylococcus ${ }^{7}$.

A cardiac homograft valve bank with cryopreservation facility was established at the Institute of Cardiovascular Diseases, Madras Medical Mission, Chennai harvested 390 aortic, 400 pulmonary and 39 others valves including mitral, of which 176 (29.9\%) hearts were discarded for various reasons which included failure to sterilize, HBV, HIV, $\mathrm{HCV}$, Treponema pallidum hemagglutination test positivity, atheromatous/fatty streaks, incompetent valves, and dissection mistakes. The valves were sterilized using an antibiotic cocktail of vancomycin, amikacin, streptomycin, cefotaxime and amphotericin B in Hank's balanced salt solution.

Of the 585 valves issued for clinical use, 247 were aortic, 323 pulmonary and 15 others (mitral valve, pericardium, conduits). Gram-negative bacilli were the predominant contaminants from the hearts during the first half (July 1995 to February 1999) and Gram-positive organisms were the predominant contaminants during the later half (March 1999 to March 2003) of the study period. A variety of fungal contaminants like candida, aspergillus, penicillium and other fungi were also isolated from the homograft hearts at procurement ${ }^{8}$.

Advantages of homograft use for cardiac valve replacement include low risk of thromboembolism, freedom from anticoagulation, low transvalvular gradient (particularly in small size valves) and resistance to infection, while disadvantages include a more demanding surgical technique (and particularly significant operative difficulty in case of re-operation), progressive degeneration of the graft and limited access to the existing "Homograft Banks 9 .

\section{References}

1. Angell WW, Angel JD. Clinical and experimental comparisons establishing the glutaraldehyde treated xenograft as the standard for tissue heart valve replacement. In: Tissue heart valves. Ionescu M (ed). London, Butterworth's, 1979, pp 89-126.

2. Strickett MG, Barratt-Boyes BG, MacCulloch D. Disinfection of human heart valve allograft with antibiotic in low concentration. Pathology 1983; 15: 457-62. 
3. Goffin Y, Grandmougin D, Van-Hoeck B. Banking cryo-preserved heart valves in Europe: Assessment of a 5 -year operation in an international tissue bank in Brussels. Eur J Cardiothorac Surg. 1996; 10: 505-12.

4. Wright JTM. Hydrodynamic evaluation of tissue valves. In: Ionescu M (ed), Tissue heart valves. London, Butterworth's, 1979, pp 29-87.

5. Kirklin JW, Barratt-Boyes BG. Aortic valve disease. In: Cardiac Surgery. Kouchoukos NT, Blackstone EH, Doty DB, Hanley FL, Karp RB (eds). $3^{\text {rd }}$ ed. USA, Elsevier Science, 2003 pp 640-42.

6. Lang SJ, Giordano MS, Cardon Cardo C, Summers BD, Staiano Coico L, Hajjar DP. Biochemical and cellular characterization of cardiac valve tissue after cryo- preservation. J Thorac Cardiovasc Surg. 1994; 108: 6367.

7. Tabaku M, Jashari R, Carton HF, Du Verger A, Van Hoeck B, Vanderkelen A. Processing of cardiovascular allografts: Effectiveness of European Homograft Bank (EHB) antimicrobial treatment (cool decontamination protocol with low concentration of antibiotics). Cell Tissue Bank. 2004; 5: 261-66.

8. Verghese S, Padmaja P, Sindhu B, Elizabeth SJ, Lesley $\mathrm{N}$, Cherian KM. Homograft valve bank: Our experience in valve banking. Indian Heart J. 2004; 56: 299-306

9. Anastasiadis K, Kambouroglou D, Spanos P. The use of valve homografts and autografts in adult cardiac surgery. Hellenic J Cardiol. 2004 45: 36-41. 